\title{
The study of the ferroconcrete beams with thrust on the foil bearings during short-term dynamic loading
}

\author{
Oleg Kumpyak ${ }^{1}$, and Daud Galyautdinov ${ }^{1 *}$ \\ ${ }^{1}$ Tomsk State University of Architecture and Building, 634003 Tomsk, Russia
}

\begin{abstract}
While designing and maintaining ferroconcrete beam constructions subjected to a short-term dynamic loading, it is necessary to consider the emergence of the thrust reaction; this leads to a considerable increase of durability and fracture strength. It is also necessary to consider the use of foil bearings as the power-intensity increase of the researched constructions. The aim of the experimental research is to expose the reasonability of using foil bearings in thrust constructions. The paper presents the results of the experimental research of ferroconcrete beam constructions with thrust on foil bearings during short-term dynamic loading. The influence of the thrust on the durability, deformability and fracture strength of ferroconcrete constructions during short-term dynamic loading, as well as joint use of foil bearings and limitation of support contour horizontal shift are studied. The results of the research indicate the positive effect of using foil bearings in the constructions with thrust.
\end{abstract}

\section{Introduction}

The existing analytical methods of calculating ferroconcrete constructions during a shortterm dynamic loading are based on the preconditions which do not always fully consider the peculiarities of the actual operation of the construction. A considerable part of bendable constructions has connections in the bearing part; these connections prevent from horizontal shift of the bearing sections at the loading and lead to thrust reaction emergence. A group of scientists carried out experimental-theoretical researches which exposed a considerable positive effect of considering the thrust reaction to the deflected mode of bendable structures [1-5].

The thrust under static influence is studied sufficiently $[1,3,5]$. The results of the analytical calculations of the constructions on the effect of static loadings with thrust indicate the increase of their bearing ability depending on the percentage of the crosssection reinforcement $(\mu)$ and the yielding of the bearing contour $(c)$ [3].

Under the dynamic influence the impact of the thrust on the constructions' resistance is ambiguous: on the one hand, the presence of the horizontal reaction increases the bearing

\footnotetext{
*The corresponding author: DaudG@yandex.ru
} 
ability of the element, on the other hand, it decreases its deformability; this leads to the reduction of the deformation plastic phase. This issue is scrutinized in the works of N. N. Popov and B. S. Rostorguev [6], T. N. Vinogradova [3], and I. N. Tikhonov [5].

Dynamic loading on buildings and constructions makes special demands of providing survivability of separate constructions and of a building as a whole $[7,8,9]$. The use of foil bearings leads to the decrease of the resistance of buildings' constructions and buildings to the influence of dynamic loadings due to the energy absorption of the dynamic influence. The results of the experimental research of bendable constructions $[9,10,11,12]$ on foil bearings demonstrate high efficiency of their use under the influence of high intensity dynamic loadings. The maximum effect is observed during the deformation of bearings at the elastoplastic phase.

The issue of the optimization of foil bearings' parameters in statically indefinable systems under a short-term dynamic loading is a new task which is topical and which requires the further study.

\section{Experiment}

With the aim of experimental evaluation of the deflected mode of ferroconcrete beam constructions on foil bearings with thrust under short-term loading the following research programme was elaborated and implemented (Table 1).

Table 1. The programme of the experimental research.

\begin{tabular}{|c|c|c|c|c|c|}
\hline Type of loading & \multicolumn{4}{|c|}{ Short-term dynamic } \\
\hline Type of bearings & $\begin{array}{c}\text { Rigid } \\
\text { supports }\end{array}$ & \multicolumn{3}{|c|}{ Foil bearings } \\
\hline $\begin{array}{c}\text { Work stage of } \\
\text { foil bearings }\end{array}$ & $\begin{array}{c}\text { Elastic-plastic } \\
\text { with hardening }\end{array}$ & \multicolumn{3}{|c|}{ Elastic-plastic } \\
\hline $\begin{array}{c}\text { Hardness of foil } \\
\text { bearings, } l, \mathrm{~mm}\end{array}$ & - & 50 & 100 & 160 & 180 \\
\hline $\begin{array}{c}\text { Code of the } \\
\text { sample }\end{array}$ & BDP-1 & BDPFh-2 & BDPFe-3 & BDPFe-4 & BDPFe-5 \\
\hline Amount & 1 & 1 & 1 & 1 & 1 \\
\hline
\end{tabular}

Notation conventions: «B» is a ferroconcrete beam; «D» is a short-term dynamic loading (drop of the load weighed $450 \mathrm{~kg}$ from the height $1150 \mathrm{~mm}$ ); «P» is the presence of the thrust construction; $\langle\mathrm{F}\rangle$ is a foil bearing (made from hollow pipes: the outside diameter is $32 \mathrm{~mm}$, the inside diameter is $26.1 \mathrm{~mm}$ ) working at the elastoplastic phase «e» or at the hardening phase $\langle h » ; \ll 1 \ldots 5 »$ is the ordinal number of the construction.

The beams with the dimensions $1900 \times 150 \times 220 \mathrm{~mm}$ are designed and made. The concrete is heavy, of class B35. The beams are reinforced with spatial framework. The cold-deformed reinforcement $\varnothing 5 \mathrm{~mm}$ of class Bp500, set with a step of $50 \mathrm{~mm}$ in the close to bearing zone and $130 \mathrm{~mm}$ in the middle of the span, is used as a cross reinforcement; the hot-rolled reinforcement $\varnothing 6 \mathrm{~mm}$ of class A240 in the compression area and $\varnothing 10 \mathrm{~mm}$ of class A500 in the tension area is used as a longitudinal reinforcement. To reinforce end areas of the beams nets with cells of $50 \times 50 \mathrm{~mm}$ from cold-deformed reinforcement $\varnothing 5 \mathrm{~mm}$ of class Bp500 were used, 7 nets on each side, and angle bars $100 \times 10 \mathrm{~mm}$ were set (Fig. 1). 

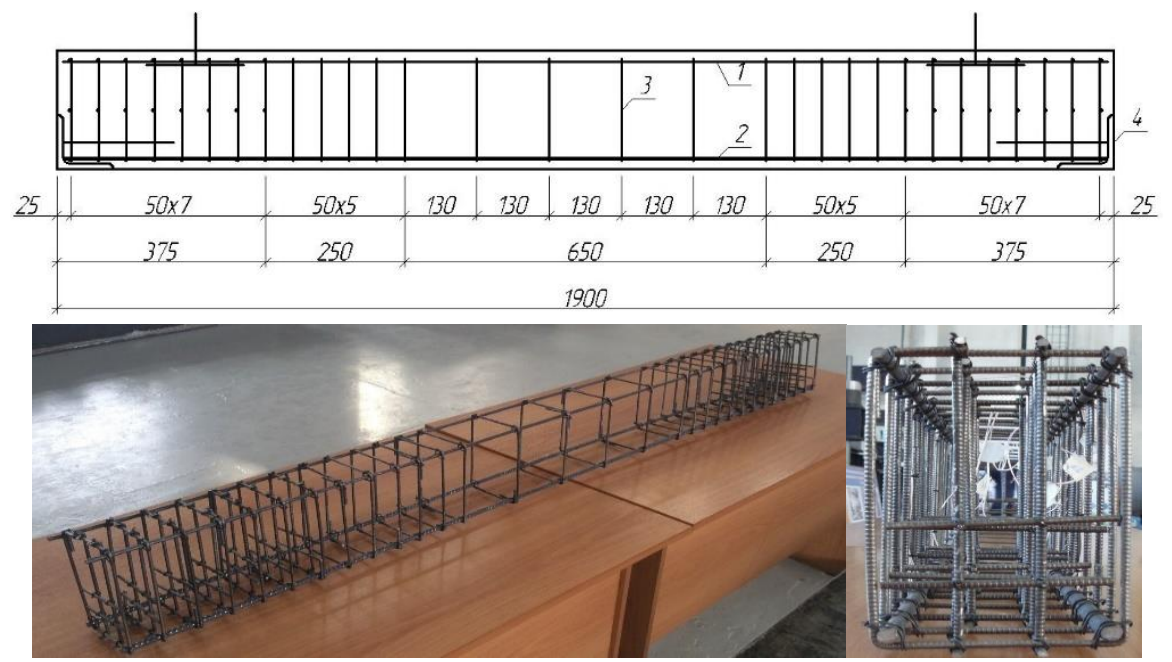

Fig. 1. The scheme of reinforcement of the researched ferroconcrete constructions: reinforcement $\varnothing 6$ $\mathrm{mm}$ of class A240 (1); reinforcement $\varnothing 10 \mathrm{~mm}$ of class A500 (2); reinforcement $\varnothing 5 \mathrm{~mm}$ of class Bp500 (3); equilateral angle bar $100 \times 10 \mathrm{~mm}$ (4).

For conducting the test a complex of measuring devices was placed on the samples: to determine the shift the inductive sensors of location Waycon of series RL150 were used. To measure the accelerations the accelerometers (DHE 100023) were used. The forcemeasuring tensoresistant sensor DST 4126 was used to determine the system reaction; and dynamometric bearings (Patent of RF for a useful model №161908) were used to determine the value of bearings' reactions. The devices were connected to the computers Mic-036R and Mic-400D.

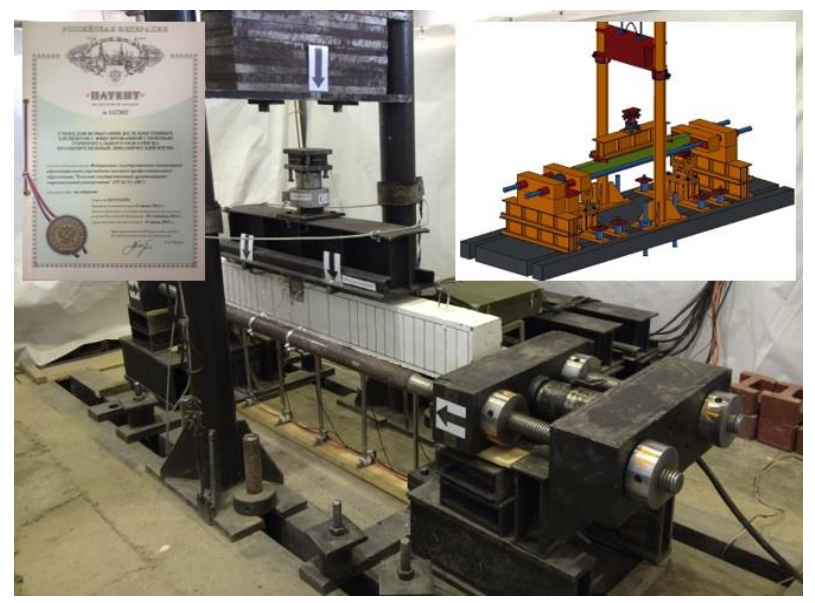

Fig. 2. The stand for testing the construction under the conditions of the limited horizontal shift under a short-term dynamic loading (a photo, a three-dimensional model).

To implement the programme of the experimental research a stand was designed and manufactured (Fig. 2), the corresponding patent was obtained (Patent of RF for a useful model №147262). A short-term dynamic loading was created by means of a falling load weighed $450 \mathrm{~kg}$ from the height of $750 \mathrm{~mm}$ (Fig. 2). 
The tested ferroconcrete beam is placed on the dynamometric bearings, providing hinged support. The bearings are fixed on the power floor, and then the initial longitudinal effort is created by the hydro jack through the system of traverse joint guide rods.

\section{Results}

By the results of the dynamic tests the graphic dependencies over the time are drawn up for the following parameters: the input force influence (Fig. 3); the construction shift without considering the mutilation of foil bearings (Fig. 4); the deformation of foil bearings (Fig. 5); the acceleration of the system (beam-yielding bearings) (Fig. 6).

Figure 3 shows that the presence of foil bearings leads to the decrease of the peak value of the input signal, while the time of reaching the maximum value is decreasing. This factor is explained as follows: the transition of foil bearings to the elastoplastic area of deformation happens later, for the obtained results in the interval of $0.007 \ldots 0.011 \mathrm{~s}$. The decrease of the deformability of statically indefinable beams is connected with the reduction of foil bearings rigidity (Fig. 4), and the more the decrease of the construction's deflection is, the more mutilation of foil bearings is. It is worth mentioning that the most efficient is the operation of foil bearings till the transition to the hardening phase, as in this case additional inertia forces emerge which lead to the growth of beams' deformation due to abrupt stop of bearings' mutilation.

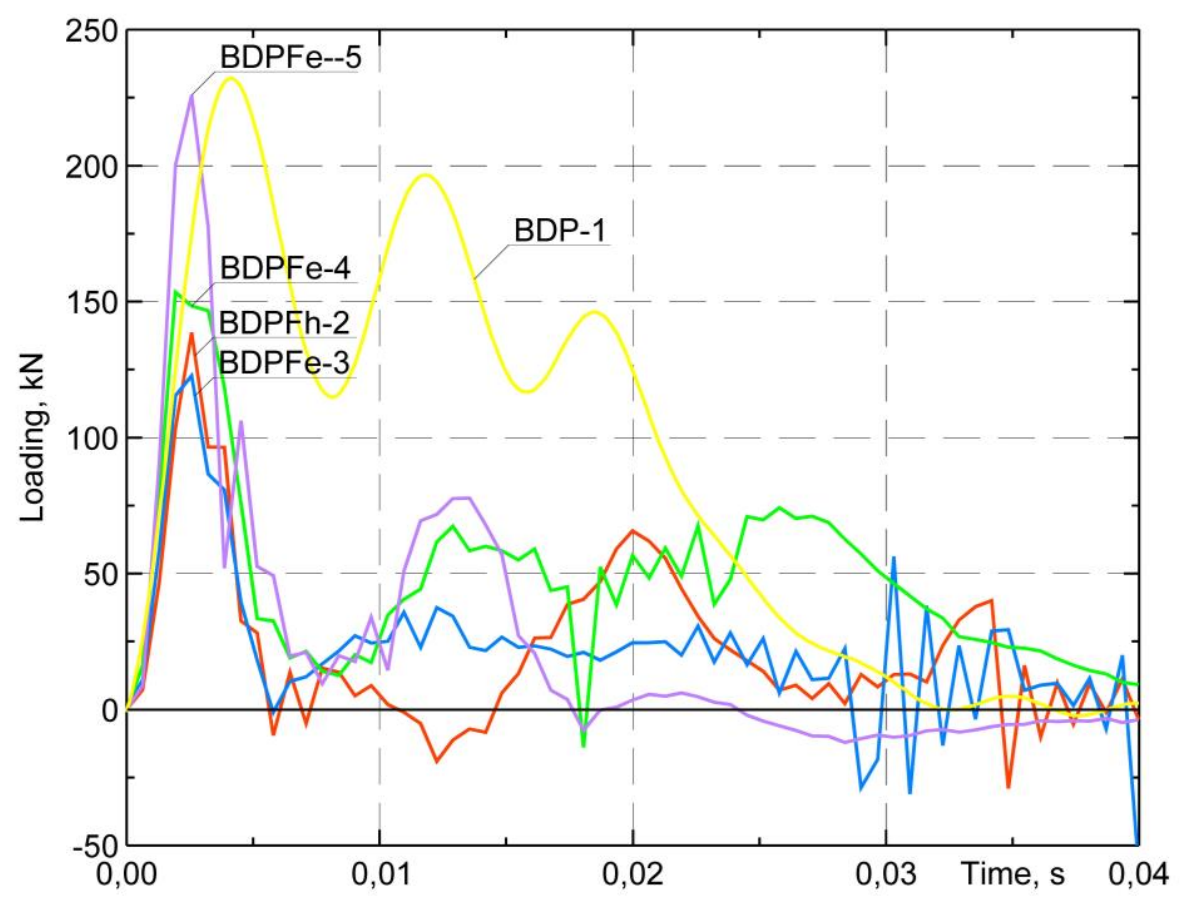

Fig. 3. The graph of the input force influence for the constructions with thrust, subjected to a shortterm dynamic loading. 


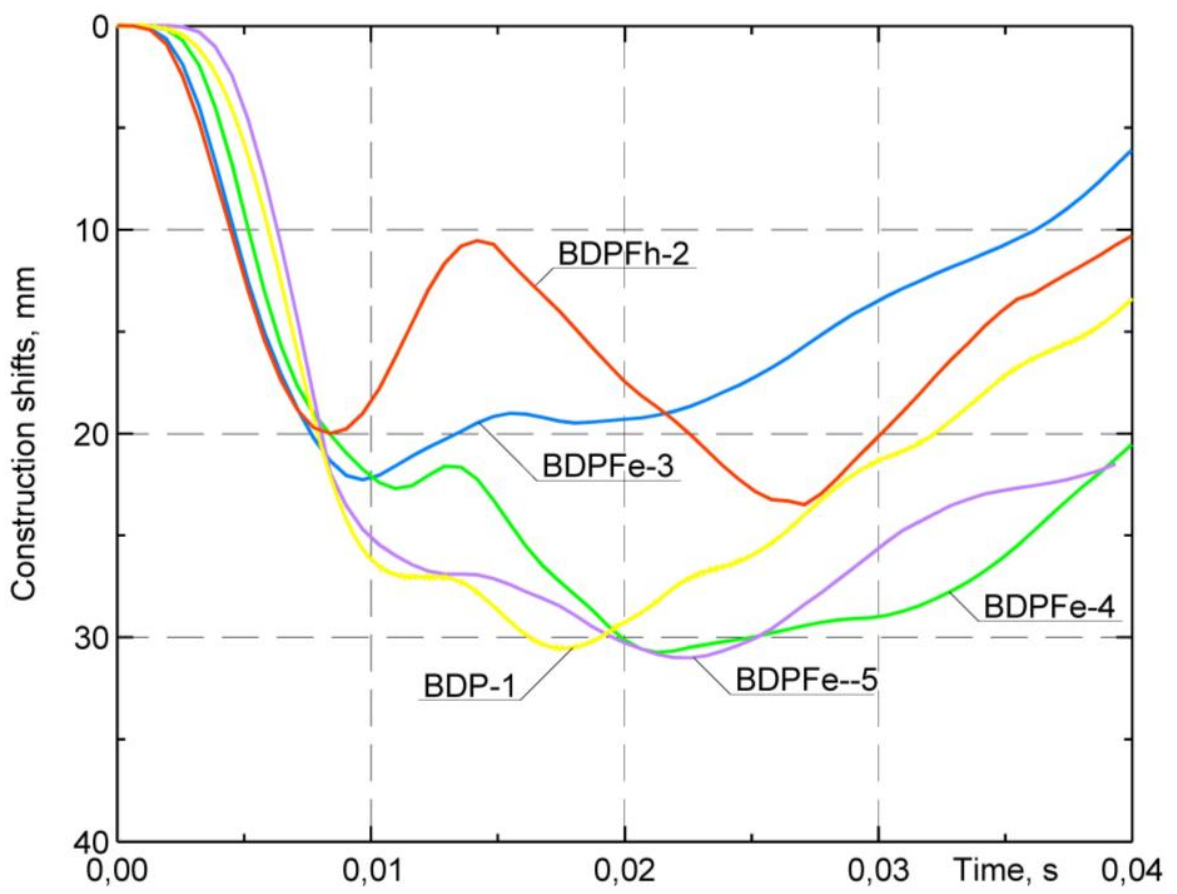

Fig. 4. The graph of the shift over time change without considering mutilation of foil bearings for the constructions with thrust, subjected to a short-term dynamic loading.

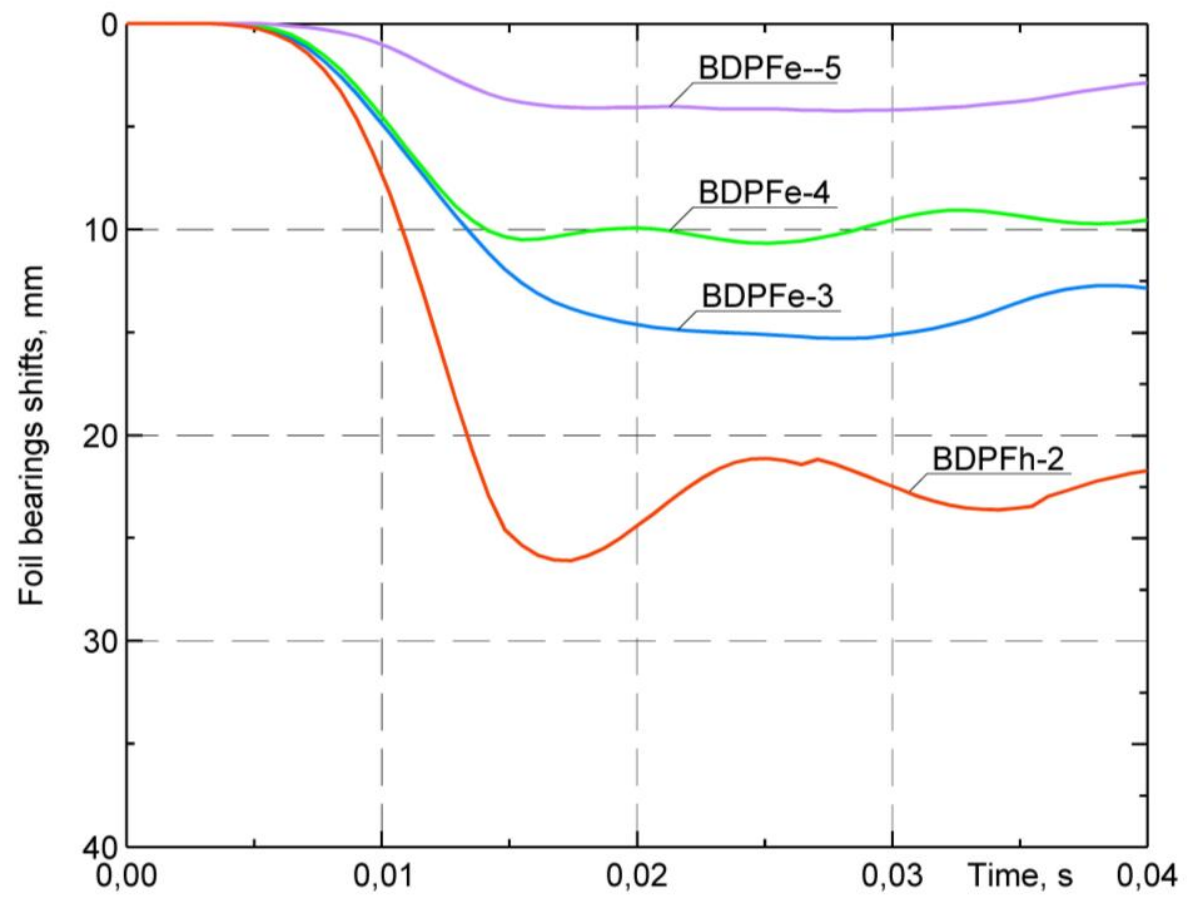

Fig. 5. The graph of the mutilation change of foil bearings for the constructions with thrust, subjected to a short-term dynamic loading. 


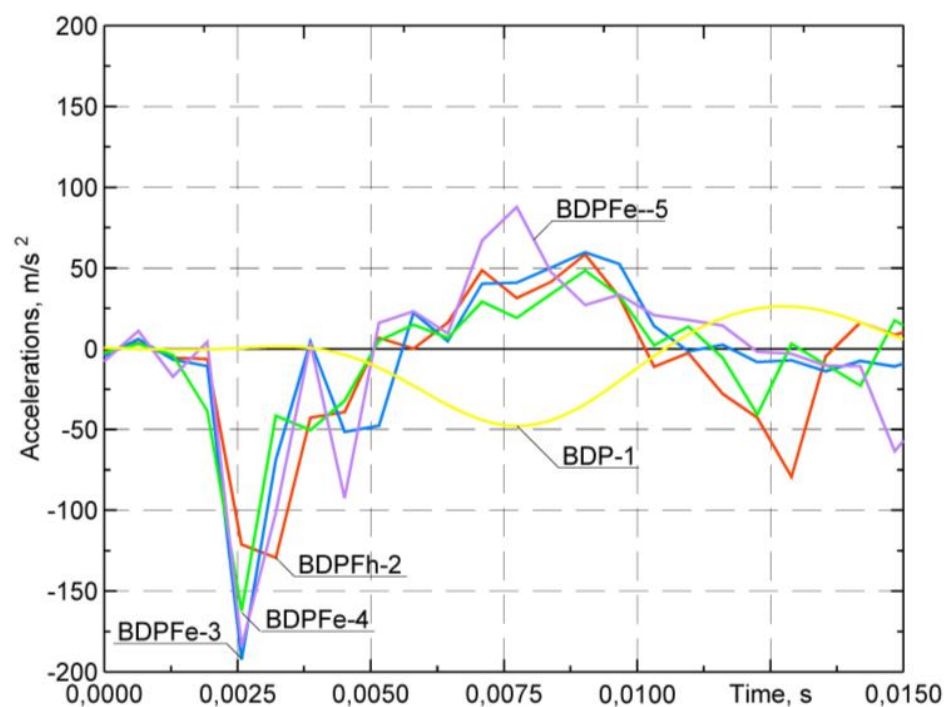

Fig. 6. The graph of acceleration change for the constructions with thrust, subjected to a short-term dynamic loading.

The analysis of the accelerations (Fig. 6) shows that the presence of foil bearings, working at the hardening phase for the beam BDPFh-2, leads to the additional growth of inertia, that is after a complete mutilation of the foil bearings (Fig. 5), the accelerations grow swiftly and aim at the peak values at the phase of elastic-plastic deformability.

\section{Conclusion}

By the results of the done experimental research it is ascertained that the use of foil bearings in the constructions, operating under the condition of the limited horizontal shift, leads to the decrease of deformability and fracture strength under the intensive dynamic loading. The increase of the system power-intensity (BDPFh-2...BDPFe-5) is observed. It is ascertained that the maximum efficiency of foil bearings is at the work in the elastoplastic area of deformation without transition to the hardening phase (BDPFe-3). The results of the experimental research also revealed hidden durability reserves of the beams on foil bearings with thrust, consideration of these parameters will allow increasing the accuracy of the calculations under short-term dynamic loading and their reliability while designing.

The reported study was funded by RFBR, project number 19-31-90097

\section{References}

1. A.A. Gvozdev, et al., Novoe o prochnosti zhelezobetona [Modern studies on reinforced concrete strength] (Strojizdat, Moscow, 1977) (in Russian)

2. L. Huynh, S. Foster, H. Valipour, R. Rendall, Construction and Building Materials 78, 153-171 (2015)

3. T.N. Vinogradova, Vlijanie raspora na rabotu zhelezobetonnyh balochnyh konstrukcij pri kratkovremennyh dinamicheskih vozdejstvijah [The effect of thrust on performance of reinforced concrete beam structures under short-term dynamic load], PhD thesis (Moscow, 1977) (in Russian) 
4. D.R. Galyautdinov, Proceedings of the $62^{\text {nd }}$ Scientific University Conference of Students and Young Researchers, 21-24 (Tomsk, Russia, 26 April, 2016) (in Russian)

5. I.N. Tikhonov, Zhilishhnoe stroitel'stvo [Housing Construction] 2, 40-45 (2013) (in Russian)

6. N.N. Popov, B.S. Rastorguev, Dinamicheskij raschet zhelezobetonnyh konstrukcij [Dynamic calculation of reinforced concrete structures] (Strojizdat, Moscow, 1974) (in Russian)

7. G.I. Odnokopilov, D.Ju. Sarkisov, E.A. Butuzov, Proceedings of Tomsk Politechnical University. Engineering of georesources 329, 122 - 135 (2018)

8. G. I. Odnokopilov, D.Ju. Sarkisov, Proceedings of Tomsk Politechnical University. Engineering of georesources 328, 85 - 95 (2017).

9. G.I. Odnokopilov, O.G. Kumpyak, Z.R. Galyautdinov, D.R. Galyautdinov, Proceedings of Tomsk Politechnical University. Engineering of georesources 330, $110-125$ (2019)

10. O.G. Kumpyak, Z.R. Galyautdinov, D.N. Kokorin, Prochnost' $i$ deformativnost' zhelezobetonnyh konstrukcij na podatlivyh oporah pri kratkovremennom dinamicheskom nagruzhenii [Strength and deformability of reinforced concrete structures on yielding supports under short-term dynamic load] (TSUAB Publ., Tomsk, 2016) (in Russian)

11. O.G. Kumpyak, Z.R. Galyautdinov. The calculation of ferroconcrete plates on foil bearings during a short-term dynamic loading // Proceedings of Tomsk State University of Architecture and Building. - Tomsk. - 2012. - № 2. - P. 107 - 111

12. O.G. Kumpyak, Z.R. Galyautdinov, D.N. Kokorin Strength of concrete structures under dynamic loading // AIP Conference Proceedings 1698, 070006 (2016); doi: 10.1063/1.4937876

13. A.R.A. Said, Povyshenie nesushhej sposobnosti zhelezobetonnyh konstrukcij pri vzryvnyh vozdejstvijah [Increase of bearing capacity of reinforced concrete structures under blast load], PhD thesis (Moscow, 1995) (in Russian) 